\title{
CONTRACTUAL CAPACITY AND THE CONFLICT OF LAWS IN COMMON-LAW JURISDICTIONS (PART 1): THE UNITED KINGDOM
}

\author{
Eesa A Fredericks \\ BA LLB LLM Dr Jur \\ Senior Lecturer, Department of Mercantile Law \\ University of Johannesburg
}

\section{SUMMARY}

This series of two articles provides a comparative overview of the position in the common-law conflict of laws in respect of the contractual capacity of natural persons. The comparative study is undertaken in order to provide guidelines for the future development of South African private international law. Reference is primarily made to case law and the opinions of academic authors. The legal position in the law of the United Kingdom, as the mother jurisdiction in Europe, is investigated in part I. Although Scotland is a mixed civil/common-law jurisdiction, the situation in that part of the United Kingdom is also discussed.

Part II will deal with the rules and principles of private international law in respect of contractual capacity in Australasia (Australia and New Zealand), North America (the common-law provinces of Canada and the United States of America), Asia (India, Malaysia and Singapore) and Africa (Ghana and Nigeria). Part II also contains a comprehensive summary of the legal position in the common-law countries, followed by ideas for the reform of South African private international law in this regard.

\section{INTRODUCTION}

This series of two articles deals with the law applicable to the contractual capacity of natural persons in the common-law systems. ${ }^{1}$ The comparative study is undertaken to provide guidelines for the future development of South African private international law in this regard. ${ }^{2}$ Common-law jurisdictions have often provided guidance to the South African courts in private international legal issues, especially in the field of the law of obligations. $^{3}$ This is also historically justified due to the immense influence

This contribution is based on Fredericks Contractual Capacity in Private International Law (Dr Jur thesis, University of Leiden) 2016 ch 3.

See par 8.

3 Schoeman, Roodt and Wethmar-Lemmer Private International Law in South Africa (2014) par 99. 
the Roman-Dutch authors had on the development of English private international law. ${ }^{4}$

The relevant position in the law of the United Kingdom, as the mother jurisdiction, is investigated in part I below. ${ }^{5}$ Although Scotland is a mixed civil/common-law jurisdiction, the legal position in that part of the United Kingdom is also discussed. ${ }^{6}$ Part II deals with the rules and principles of private international law in respect of contractual capacity in Australasia (Australia; and New Zealand), North America (the common-law provinces of Canada; the United States of America); Asia (India; Malaysia; and Singapore); and Africa (Ghana; and Nigeria). The particular jurisdictions were chosen on the basis of the availability of sources and the cultural and/or economic importance of the country. Part II includes a comprehensive overview of the position in the common-law conflict of laws, ${ }^{7}$ which could in due course be taken into account in the reform of South African private international law in this field. ${ }^{8}$

The legal position in South Africa today in respect of the legal system applicable to contractual capacity is completely unclear. ${ }^{9}$ There is no binding judicial authority in South Africa in this regard; decisions from neither the Supreme Court of Appeal (or its predecessors) nor the Constitutional Court exist.

The Roman-Dutch authors suggested the application of the lex domicilii (the law of the country of domicile of the alleged incapable party) or the lex loci contractus (the law of the country where the contract was concluded) with some flexibility, taking into account the need for an equitable outcome in the particular case. ${ }^{10}$ Some of the authors argued in favour of the application of the lex situs (the law of the country where the property is situated) in respect of immovable property. ${ }^{11}$ All these views were received into South African case law.

The court in Hulscher $v$ Voorschotkas voor Zuid Afrika ${ }^{12}$ refers to the lex domicilii and the lex loci contractus as possible systems to govern contractual capacity, without choosing between them - they coincided in

4 See Forsyth "The Provenance and Future of Private International Law in Southern Africa" 2002 TSAR 60.

See par 2.

See par 212

See par 7.

See par 8.

See, in general, Edwards-Kahn LAWSA II.2 Conflict of Laws (2003) par 308 and 333; Forsyth Private International Law. The Modern Roman-Dutch Law including the Jurisdiction of the High Courts 5ed (2012) 292-295 and 337-341; Fredericks Contractual Capacity in Private International Law ch 2; Schoeman et al Private International Law in South Africa par 107-115; and Van Rooyen Die Kontrak in die Suid-Afrikaanse Internasionale Privaatreg (1972) 120-126.

10 Forsyth Private International Law. The Modern Roman-Dutch Law including the Jurisdiction of the High Courts 338. Also see Fredericks "The Common-Law Authors on Contractual Capacity in Private International Law" 201536 Obiter 762 for an overview of the opinions of the Roman-Dutch authors in this regard.

11 Ibid

121908 TS 542. 
casu. ${ }^{13}$ Kent $v$ Salmon ${ }^{14}$ is clear authority in favour of the lex loci contractus $^{15}$ and Powell $v$ Powell ${ }^{16}$ should be read as support for the lex domicilii. ${ }^{17}$ The court in Guggenheim v Rosenbaum (2) ${ }^{18}$ refers to authority in favour of the lex loci contractus and the lex domiciliii ${ }^{19}$ but it is clear that the lex domicilii would have been favoured if the two did not coincide in casu. ${ }^{20}$ The court in Tesoriero $v$ Bhyjo Investments Share Block (Pty) Ltd ${ }^{21}$ is critical about the application of the lex loci contractus and clearly favours the proper law of the contract to govern capacity. ${ }^{22}$ In casu no choice had to be made as these legal systems were the same on the facts. ${ }^{23}$ Ferraz $v$ d'Inhaca ${ }^{24}$ is the only case dealing with immovable property; here it was decided that the lex situs should apply. ${ }^{25}$

When referred to in the context of contractual capacity, the proper law of the contract must invariably refer to the putative proper law, as in the absence of contractual capacity no contract comes into existence. The putative proper law is the law that would have been the proper law of the contract if a contract were indeed concluded. ${ }^{26}$

THE UNITED KINGDOM

\section{Introduction}

In the United Kingdom, the provisions of the Rome Convention on the Law Applicable to Contractual Obligations ${ }^{27}$ and the Rome I Regulation on the

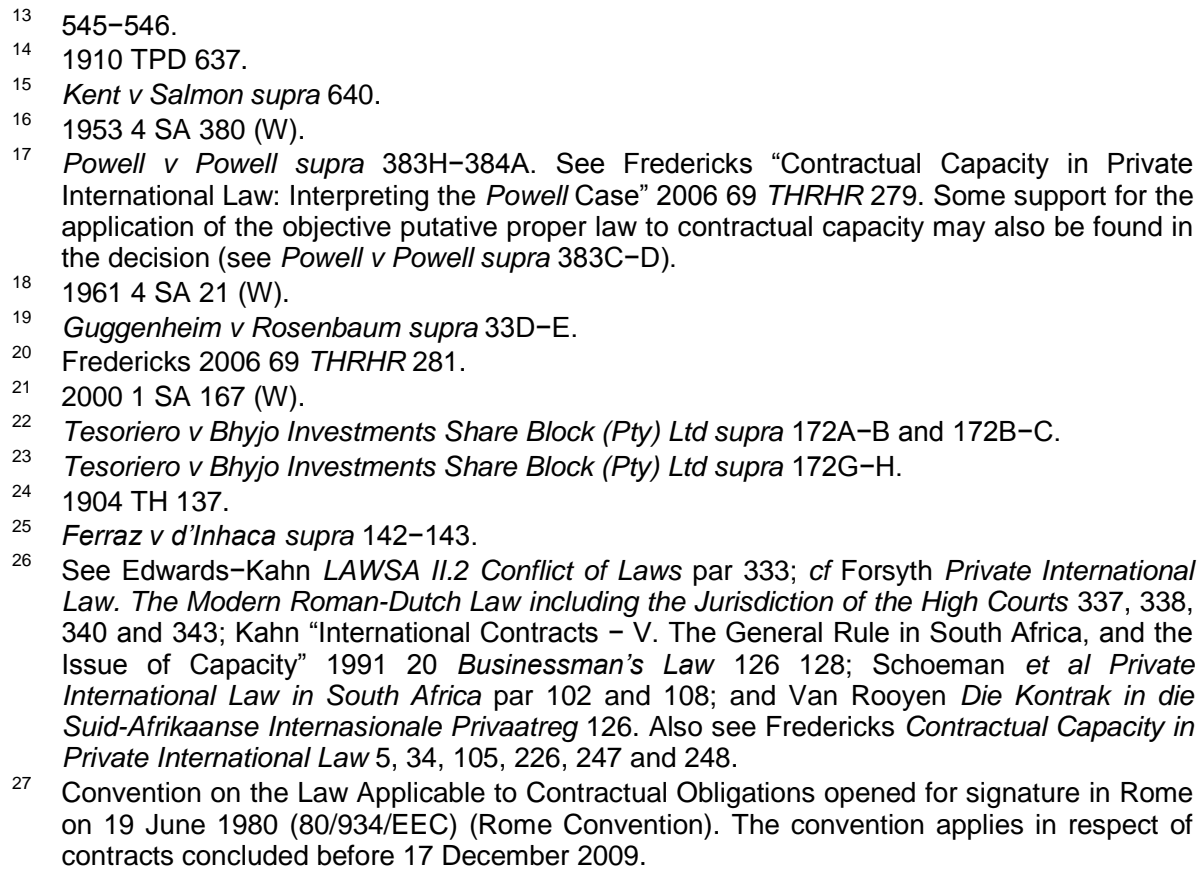

Powell v Powell supra 383H-384A. See Fredericks "Contractual Capacity in Private International Law: Interpreting the Powell Case" 200669 THRHR 279. Some support for the application of the objective putative proper law to contractual capacity may also be found in the decision (see Powell $v$ Powell supra 383C-D).

1819614 SA 21 (W).

9 Guggenheim v Rosenbaum supra 33D-E.

Fredericks 200669 THRHR 281.

20001 SA 167 (W).

Tesoriero v Bhyjo Investments Share Block (Pty) Ltd supra 172A-B and 172B-C.

Tesoriero v Bhyjo Investments Share Block (Pty) Ltd supra 172G-H.

$1904 \mathrm{TH} 137$.

Ferraz $v$ d'Inhaca supra 142-143.

26 See Edwards-Kahn LAWSA II.2 Conflict of Laws par 333; cf Forsyth Private International Law. The Modern Roman-Dutch Law including the Jurisdiction of the High Courts 337, 338, 340 and 343; Kahn "International Contracts - V. The General Rule in South Africa, and the Issue of Capacity" 199120 Businessman's Law 126 128; Schoeman et al Private International Law in South Africa par 102 and 108; and Van Rooyen Die Kontrak in die Suid-Afrikaanse Internasionale Privaatreg 126. Also see Fredericks Contractual Capacity in Private International Law 5, 34, 105, 226, 247 and 248.

27 Convention on the Law Applicable to Contractual Obligations opened for signature in Rome on 19 June 1980 (80/934/EEC) (Rome Convention). The convention applies in respect of contracts concluded before 17 December 2009. 
Law Applicable to Contractual Obligations ${ }^{28}$ govern the law applicable to contractual obligations. In general, the status or legal capacity of natural persons is excluded from the scope of the Convention and the Regulation, ${ }^{29}$ perhaps because it could be seen to form part of the law of persons and not of obligations. ${ }^{30}$ Member states therefore apply their domestic private international law rules to the issue of contractual capacity. ${ }^{31}$ This is, however, subject to the provisions of article 11 of the Convention and article 13 of the Regulation, which both contain a case-specific rule directed at protecting innocent parties who have contracted with a contractant lacking capacity. $^{32}$

\section{England and Wales}

There is uncertainty regarding the position in England and Wales on the law applicable to contractual capacity. ${ }^{33}$ It is clear, however, that the choice lies between the lex domicilii, the lex loci contractus and the proper law of the contract. Some support also exists for the application of the lex situs in respect of immovable property.

\section{The courts}

\section{Introduction}

The most important cases applying the lex domicilii to contractual capacity are Sottomayor $v$ De Barros (1), ${ }^{34}$ Cooper $v$ Cooper $^{35}$ and Baindail $v$ Baindail. ${ }^{36}$ These cases relate to the conclusion of marriages and antenuptial contracts. However, the courts make general statements in respect of contractual capacity that have been accepted as authority for the

28 Regulation (EC) No 593/2008 of the European Parliament and of the Council of 17 June 2008 on the Law Applicable to Contractual Obligations (Rome I). The regulation applies to contracts concluded as from 17 December 2009.

29 Art 1(2)(a) of both the Rome Convention and the Rome I Regulation.

30 See Clarkson and Hill The Conflict of Laws 4ed (2011) 249; O'Brien Smith's Conflict of Laws 2ed (1999) 350; and Rogerson Collier's Conflict of Laws 4ed (2013) 320.

31 Fawcett and Carruthers Cheshire, North and Fawcett Private International Law 14ed (2008) 750.

32 Arts 11 and 13 are discussed in Fredericks Contractual Capacity in Private International Law 177-190 and Fredericks "The Conflicts Rule in Respect of Contractual Capacity in the Preliminary Draft Uniform Act on the Law of Obligations in the OHADA Region" 2018 SA Merc LJ (forthcoming).

33 Carter "Contracts in English Private International Law" 198757 British Yearbook of International Law 23; Cheng The Rules of Private International Law Determining Capacity (1916) 3 and 63; Clarkson and Hill The Conflict of Laws 249; Collier Conflict of Laws (1987) 168; Collins et al (eds) Dicey, Morris and Collins on the Conflict of Laws 15ed (2012) 1866; Fawcett and Carruthers Cheshire, North and Fawcett Private International Law 750; Fawcett, Harris and Bridge International Sale of Goods in the Conflict of Laws (2005) 657; Hill and Chong International Commercial Disputes. Commercial Conflict of Laws in English Courts 4ed (2010) 550; McClean and Beevers Morris The Conflict of Laws 7ed (2009) 385; 'Brien Smith's Conflict of Laws 318; and Rogerson Collier's Conflict of Laws 320.

(1877) 3 PD 1

35 (1888) 13 App Cas 88.

36 [1946] P 122. 
application of the lex domicilii to contractual capacity in general, ${ }^{37}$ and, in respect of Baindail $v$ Baindail, ${ }^{38}$ for the application of the lex loci contractus.

\section{Sottomayor $v$ De Barros $(1)^{39}$}

Sottomayor and De Barros were Portuguese nationals and domiciled in Portugal. They relocated to England in 1858 with their families and jointly occupied a house in London. The decision of the court was based on the assumption that they retained their domicile in Portugal. Although they were first cousins, ${ }^{40}$ they married in London on 21 June 1866. In November 1874, Sottomayor petitioned the court a quo that her marriage to De Barros be declared null and void on the grounds that they were natural and lawful first cousins, and that, according to their domiciliary law (Portuguese law), such relatives were incapable of concluding a marriage contract on account of consanguinity. Sir R Philmore, however, rejected the petition because he considered himself bound by the decision in Simonin $v$ Mallac ${ }^{41}$ where it was held that the validity of a marriage is determined by the lex loci celebrationis (the law of the country where the marriage is concluded). The marriage was valid as no such prohibition existed in English law. The current case is the appeal by Sottomayor against the decision taken by Sir Philmore.

The Court of Appeal, through Cotton LJ, held that it was a wellestablished principle that "the question of personal capacity to enter into any contract [was] to be decided by the law of domicile". ${ }^{2}$ The law of the country where the marriage was solemnised only addressed issues relating to the validity of the ceremony by which the marriage was constituted; it played no role in personal capacity as this would "depend on the law of domicile". ${ }^{43}$ The court also stated that if the laws of any country prohibit a marriage between parties because of it being incestuous, this would impose personal incapacity on them that would continue for as long as they are domiciled in the country where this rule prevails. ${ }^{44}$ As such, the court reversed the judgment by Sir Philmore and declared the marriage null and void.

For current purposes, the general statement of the court is relevant that contractual capacity is governed by the lex domicilii. ${ }^{45}$

37 See, for instance, Cheng The Rules of Private International Law Determining Capacity 113-121; Collins et al Dicey, Morris and Collins on the Conflict of Laws 15ed 1867; and Fawcett and Carruthers Cheshire, North and Fawcett Private International Law 750.

Supra.

Supra.

This means that Sottomayor and De Barros were the children of siblings.

412 Sw \& $\operatorname{Tr} 67 ; 29$ L J (P M \& A) 97. This case concerned the validity of a marriage concluded in England between a Frenchman of 29 and a Frenchwoman of 22. Although both parties had attained the age of majority in terms of art 148 of the French Civil Code (25 years for men and 21 for women), the advice of their parents still had to be obtained through a "respectful and formal act" according to art 151. The parties were not successfu in obtaining this and apparently failed to effect repeated attempts described in art 152 of the code. The marriage was therefore not permitted. The marriage was, however, held lawful in England as it was valid in terms of English law.

42 Sottomayor $v$ De Barros (1) supra 5.

43 Ibid.

44 Ibid.

45 Ibid. 


\section{Cooper $v$ Cooper ${ }^{46}$}

Mr and Mrs Cooper were married in Dublin (Ireland) in October 1846. At that stage, the parties were domiciled in Scotland and Ireland respectively. At the time of marriage, Mrs Cooper was a minor and had no legal guardians. An antenuptial contract was concluded between the parties in Dublin, where after they relocated to Scotland. Here they resided for the remainder of their married lives. In terms of the contract, Mrs Cooper, in consideration of provisions made by her husband, purported to relinquish her rights to terce ${ }^{47}$ and jus relictae. ${ }^{48}$ Upon Mr Cooper's death, she instituted action for the setting aside of this contract on the grounds that she was a minor at the time of concluding it and that, in terms of Irish law, she lacked capacity to enter into an antenuptial contract.

The court held that Mrs Cooper's incapacity, in terms of Irish law, was a sufficiently substantial ground for setting aside the contract. The court added that Mrs Cooper's capacity to bind herself by the antenuptial contract had to be determined by the law of the country of her domicile, which in casu was Irish law. ${ }^{49}$ In applying Irish law, the court held that a minor could not incur any contractual liability when this was clearly not to his or her benefit and, consequently, Mrs Cooper was at liberty to avoid the contract and claim her rights as a widow in terms of the law of Scotland. ${ }^{50}$ With regard to the law applicable to capacity, Lord Macnaughten made the following important remarks:

"It has been doubted whether the personal competency or incompetency of an individual to contract depends on the law of the place where the contract is made or on the law of the place where the contracting party is domiciled. Perhaps in this country the question is not finally settled, though the preponderance of opinion here as well as abroad seems to be in favour of the law of the domicil. It may be that all cases are not to be governed by one and the same rule. But when the contract is made in the place where the person whose capacity is in question is domiciled there can be no room for dispute. It is difficult to suppose that Mrs Cooper could confer capacity on herself by contemplating a different country as the place where the contract was to be

46 Supra.

47 In Scottish law, this related to a widow's legal entitlement to a liferent of one-third of her husband's heritable property (her entitlement in respect of his moveable property being the jus relictae). A liferent was a right entitling a person (called a "liferenter") to use and enjoy another's property for life, provided this was done without wasting it. The liferent might be a sum of money paid yearly, or the income from a piece of land. If a special alternative provision had been made for her in her marriage contract (the jointure), she would, after 1681, have lost her right to a terce, unless it had been specified in the contract that she should have that as well. See DSL Dictionary of the Scots Language / Dictionar o the Scots Leid http://www.dsl.ac.uk/entry/snd/terce (accessed 2018-07-28).

48 Literally translated, "the right of the relict" (the widow). It refers to the share of the moveable goods of a marriage to which a widow was entitled on the death of her husband. If there were children, one-third would go to them as the bairn's pairt of gear (children's legal share of their parents' moveable property on their death, also called the legitim), a further onethird would be the portion the deceased could bequeath and the jus relictae was the other. See DSL http://www.dsl.ac.uk/entry/snd/jus_relictae (accessed 2018-07-28).

49 Cooper $v$ Cooper supra 106.

50 Ibid. 
fulfilled, if that be the proper expression, or by contracting in view of an alteration of personal status which would bring with it a change of domicile."

The court states its preference for the lex domicilii as the governing legal system. A party should be unable to confer capacity on him- or herself by contracting in a country other than the country of domicile. In any event, where the lex domicilii and the lex loci contractus coincide, it will unquestionably be the lex domicilii / lex loci contractus that applies.

\section{Baindail $v$ Baindaif ${ }^{2}$}

On 1 May 1928, the respondent, Mr Baindail, while domiciled in India, married an Indian lady according to Hindu rites in the United Provinces, India. The marriage was polygynous in nature according to the Hindu faith. ${ }^{53}$ On 5 May 1939, while his wife was still alive, he entered into marriage with the petitioner, Lawson, in Holborn (England). The couple cohabited in England and they had one child, a daughter, born on 22 February 1940. The petitioner, however, became aware of the respondent's Hindu marriage and, on 20 May 1944, petitioned for a decree that her marriage was null and void and that she might obtain custody of the child.

In addressing the issue of capacity to contract, Lord Greene MR held that, in general, the lex domicilii should be applied. Applying this legal system (which was Indian law in casu), he arrived at the conclusion that the respondent was a married man on 5 May 1939, the date of his purported English marriage. As to the polygymous nature of the marriage, Lord Greene stated: "[W]hatever Hindu law may say and whatever his position may be in India, this country will not recognize the validity of the Hindu marriage." ${ }^{54}$ Nevertheless, as he did not have the capacity to conclude a marriage at the time of his English marriage, the latter was declared null and void. The petitioner was declared to be the custodian of the child.

Although the lex domicilii was applied to capacity in a marital context, Lord Greene clearly favoured the application of the lex loci contractus in commercial transactions. He stated obiter that "[i]n the case of infants where different countries have different laws, it certainly is the view of high authority here that capacity to enter in England into an ordinary commercial contract is determined not by the law of domicile but by the lex loci". ${ }^{55}$ In the statement that follows this remark, he clearly demonstrates his objection to the exclusive application of the lex domicilii: "[T]here cannot be any hard and

Cooper v Cooper supra 108.

2 Supra.

53 In India, Hindu marriages can since 1955 no longer be concluded on a polygynous basis: see the Hindu Marriage Act, 1955.

54 Baindail $v$ Baindail supra 127. Of course, this is no longer the position in the law of the United Kingdom (see for eg, Rule 73 of Dicey, Morris and Collins (Collins et al (eds) Dicey, Morris and Collins on the Conflict of Laws 14ed (2006) 850).

55 Baindail $v$ Baindail supra 128. Van Rooyen Die Kontrak in die Suid-Afrikaanse Internasionale Privaatreg 117, on account of this statement, accepts that the court supported the application of the lex loci contractus to commercial contracts, while Carter (1987 57 British Yearbook of International Law 24-25) adds that the judgment prima facie only applies to contracts concluded in the forum state. There does not seem to be any support in the judgment for this limitation. 
fast rule relating to the application of the law of the domicile as determining status and capacity for the purpose of transactions in this country."

\section{Male $v$ Roberts ${ }^{57}$}

In this decision and the case to follow (Sottomayor $v$ De Barros (2)), ${ }^{58}$ it was indeed decided that the lex loci contractus governs contractual capacity. Roberts, a minor and a circus performer domiciled in England, incurred liquor debt while in Edinburgh (Scotland). He consequently induced a friend, Male, to supply funds to pay for the debt as he was arrested in meditatione fugae. After Male settled the debt, he sued Roberts for the amount in England, but the latter defended the action stating that he was a minor and in terms of his domiciliary law, which was English law, he was incapable of concluding contracts unassisted.

Lord Chancellor Eldon rejected the incapacity contention by the minor and decided that the law of the country where the contract was concluded, which in this case was Scotland, should apply to contractual capacity. He stated: " $[T]$ he contract must be ... governed by the laws of that country where the contract arises." ${ }^{59}$

\section{Sottomayor $v$ De Barros (2) ${ }^{60}$}

This case involves an appeal against the decision by the Court of Appeal in Sottomayor $v$ De Barros (1), ${ }^{6}$ where first cousins domiciled in Portugal concluded a marriage in England. In the first reported Sottomayor case, the appellant (Sottomayor) approached the court to reverse the judgment of the court a quo, which held that their marriage was valid. On appeal, the court held that the personal capacity of an individual had to be determined by the lex domicilii. The Court of Appeal consequently reversed the findings of the court a quo in the first Sottomayor case, rendering the marriage null and void. ${ }^{62}$ The Queen's Proctor, however, referred the case to the Probate Division for further questions to be addressed, inter alia whether at the time of their marriage the couple was not perhaps domiciled in England. In attending to this issue, the court had to pronounce on the law applicable to contractual capacity.

56 Baindail v Baindail supra 128. Collins et al Dicey, Morris and Collins on the Conflict of Laws 14 ed 1623 regard this statement as encouraging development in the field.

57 (1800) 3 ESP 163.

58 (1879) 5 PD 94. This is the remittance of Sottomayor v De Barros (1) supra from the Court of Appeal, notwithstanding the difference in spelling of the wife's surname.

59 As referred to by Collins et al Dicey, Morris and Collins on the Conflict of Laws 15ed 1868. This decision is discussed by Anton and Beaumont Private International Law 2ed (1990) 277; Crawford and Carruthers International Private Law in Scotland 2ed (2006) 437; and Fawcett and Carruthers Cheshire, North and Fawcett Private International Law 751. The case perhaps dealt with an enrichment rather than a contractual claim: cf Collins et al Dicey, Morris and Collins on the Conflict of Laws 15ed 1868.

60 Sottomayor $v$ De Barros (2) supra.

61 Supra. This case is discussed in the text at par 21112.

62 See the discussion at par 21112. 
In casu the court held that Sottomayer was indeed domiciled in Portugal at the time of the marriage but that De Barros had changed his domicile from Portuguese to English. ${ }^{63}$ Therefore, according to the Probate Division, the decision by the Court of Appeal was incorrect. The Court of Appeal applied the lex domicilii on the supposition that both parties were domiciled in the same place, namely, Portugal: "Our opinion in this appeal is confined to the case where both the contracting parties are at the time of their marriage domiciled in a country the laws of which prohibit their marriage."64 But, according to the Probate Division, this was factually incorrect, as the matter clearly concerned a "marriage of a domiciled Englishman in England, with a woman subject to the law of her domicil [Portugal]". ${ }^{65}$ In any event, the lex domicilii was not to be applied. The Probate Division indeed severely criticised the Court of Appeal's view that the lex domicilii was generally accepted to govern contractual capacity in all matters. The Probate Division stated: "On the contrary, it appears to me to be a novel principle, for which up to the present time there has been no English authority. What authority there is seems to me to be the other way." 66 This refers to authority in favour of the application of the lex loci contractus. The Probate Division also found that the principle enunciated by the court regarding the applicability of the lex domicilii in all cases was "much wider in its terms as was necessary for the determination of the case before them". ${ }^{67}$ The Probate Division, heavily relying on the decisions in Male $v$ Roberts, ${ }^{68}$ Scrimshire $v$ Scrimshire ${ }^{69}$ and Simonin $v$ Mallac, ${ }^{70}$ held that contractual capacity should be governed by the "law of the country where the contract arose"," the lex loci contractus. In applying this legal system (English law) the court concluded that the marriage was lawful and binding upon Sottomayor.

\section{Republica De Guatemala v Nunez ${ }^{72}$}

In this case, the court had to decide on the law applicable to contractual capacity where the lex domicilii and the lex loci contractus coincided. In casu the former president of the Republic of Guatemala, Manuel Cabrera, domiciled in Guatemala, deposited a sum of money with a bank in London, England. In 1919 he donated the funds by way of a cession contract to his son Nunez, who was a minor at the time and also domiciled in Guatemala. It was common cause that the cession would have been valid if English law were applicable. In terms of Guatemalan law, however, a cession without consideration was void unless it was effected by a notary on official documentation signed by both parties. Further, according to this law, a minor could not accept a benefit under a cession voluntarily; it had to be addressed

\footnotetext{
Sottomayor v De Barros (2) supra 99.

As stated in Sottomayor v De Barros (1) supra 5.

Sottomayor $v$ De Barros (2) supra 100.

Ibid.

Ibid.

Supra.

2 Cons 412.

2 Sw \& Tr 67; 29 L J (P M \& A) 97.

Sottomayor $v$ De Barros (2) supra 100.

[1927] 1 KB 669 (CA).
} 
to, and accepted by, his or her legal representative, who should have been appointed by a judge. It was proven that none of these requirements were met in casu. After Cabrera was overthrown in 1920, the state of Guatemala laid claim to the funds on the grounds that he had wrongfully misappropriated them and that they actually were the Republic's property. On appeal, the court had to address the issue of which law governed the cession contract. This would automatically indicate whether the state's or Nunez's claim to the funds should be successful.

Scrutton LJ arrived at the conclusion that the cession contract had to be governed by Guatemalan law and was therefore void. With regard to the question of the capacity of a minor to benefit from a cession, the court held that in casu Nunez's domicile coincided with the location where the cession contract was concluded (both were in Guatemala). Consequently, it was unnecessary to determine which legal system would have applied if they had differed. ${ }^{73}$ The court was convinced that Nunez was a minor in terms of the law of Guatemala (which was both the lex domicilii and the lex loci contractus) and therefore lacked the capacity to receive the donation.

Rogerson regards this case as "confused and indeterminate". ${ }^{74}$ In fact, she states that the ratio decidendi of the case is impossible to decipher. The only possible ratio decidendi, the author continues, is that capacity to benefit under a cession contract is governed by either the lex domicilii or the lex loci actus (contractus), but this is unhelpful and inaccurate. The author submits that the proper law of the contract objectively determined should govern in this regard. If this legal system were applied to the case, Guatemalan law would almost certainly be the applicable law and would render the cession contract void. ${ }^{75}$ The result would therefore remain identical.

O'Brien is also uncertain whether any clear ratio can be extracted from the case. Without providing references, he indicates that some are of the opinion that the case may be taken as authority for the suggestion that capacity in respect of a cession contract should be governed by the proper law of the contract as determined by the lex loci actus (contractus). ${ }^{76}$ In conclusion, he submits that "[t]he question of the capacities of the assignor and the assignee, which are outside the Convention, ${ }^{77}$ should be governed by the general principles applicable to contracts - preferably the putative applicable law - rather than the old authorities, which should now be regarded as obsolete". ${ }^{78}$

73 As discussed by Clarkson and Hill The Conflict of Laws 485; Collins et al Dicey, Morris and Collins on the Conflict of Laws 15ed 1867; McClean and Beevers Morris The Conflict of Laws 387; and Van Rooyen Die Kontrak in die Suid-Afrikaanse Internasionale Privaatreg 117.

74 Rogerson Collier's Conflict of Laws 401.

75 Ibid.

76 O'Brien Smith's Conflict of Laws 573. Such a view would entail that the court applied the doctrine of renvoi.

77 Namely the Rome Convention (fn 27 above) or, today, the Rome I Regulation (fn 28 above).

78 O'Brien Smith's Conflict of Laws 573. 


\section{The Bodley Head Ltd v Flegon ${ }^{79}$}

This is the most recent case on the issue of contractual capacity of individuals in English private international law. The court in this case decided that contractual capacity should be governed by the proper law of the contract. Alexander Solzhenitsyn, the Russian author, signed a power of attorney in Moscow in favour of one Dr Heeb, a Swiss lawyer, to manage business relating to his literary works outside the Soviet Union. In terms of the power of attorney, Swiss law was applicable to any disputes between the parties. Dr Heeb ceded certain rights to a German publishing house, Hermann Luchterhand Verlag $\mathrm{GmbH}$, which authorised the plaintiff, Bodley Head Ltd, to publish Solzhenitsyn's work in the United Kingdom. The defendant, Flegon, however, intended to publish his own edition of Solzhenitsyn's work and disputed Bodley Head's rights in this regard. He submitted that in English private international law, contractual capacity was regulated by either the lex domicilii or the lex loci contractus. He further argued that, because these legal systems coincided in casu (Russia was both the country of Solzhenitsyn's domicile and the location where the contract of agency was concluded), Russian law was applicable irrespective of which test is applied. Accordingly, he submitted, the agreement between Solzhenitsyn and Dr Heeb was invalid as the former lacked capacity to enter into an international contract of agency in terms of Russian law.

With regard to the issue of the invalidity of the contract of agency in Russian law, Brightman $J$ held that this was the position not as a consequence of a lack of capacity, but because it was unlawful for a Russian citizen to conduct international trade for his or her own account. He stated, "in Russia there is a state monopoly of foreign trade under article 14 of the Russian constitution; the carrying on of business by a Russian author would also offend article 9 of the constitution". ${ }^{80}$ In other words, it was a rule of material validity rather than capacity that the court had to deal with. The judge indicated that the contract of agency was more closely connected to Switzerland ${ }^{81}$ than Russia ${ }^{82}$ and consequently that Swiss law was applicable to the contract. The proper law of the contract (Swiss law) was applied to the issue of material validity and the contract of international agency was therefore valid. Brightman $\mathrm{J}$ indicated that, even if the issue was classified as pertaining to contractual capacity, the proper law of the contract would still be applicable. Solzhenitsyn possessed the relevant capacity in terms of Swiss law, the proper law of the contract. The judge stated: "I have not been referred to any reported case which prevents my holding that, in such circumstances, the author's capacity should be tested by Swiss law. There is no evidence of the author's incapacity under that law." 83

\footnotetext{
[1972] 1 WLR 680.

The Bodley Head Ltd $v$ Flegon supra 688.

81 The Bodley Head Ltd $v$ Flegon supra 689. The contract was subject to Swiss law; the engrossment was delivered in Switzerland and the signed document was later handed to $\mathrm{Dr}$ Heeb in Switzerland. None of the parties intended that any performance should be effected in Russia but rather Switzerland.

82 The Bodley Head Ltd v Flegon supra 689: "the agency contract has no relevant connection with Russia".

83 The Bodley Head Ltd v Flegon supra 689.
} 
Hill and Chong submit that to the extent that the court in casu accepted that the (putative) proper law of the contract should, in the first instance, be determined by reference to the law of express or tacit choice, as opposed to the law of the country with which the contract has its closest and most real connection, it cannot be supported in principle. ${ }^{84}$ There is, however, no indication in the case that the proper law should primarily be subjectively determined.

\section{Bank of Africa, Limited v Cohen ${ }^{85}$}

The court in this case had to address the issues of the contractual capacity of an individual where immovable property is involved. The respondent, Mrs Cohen, was a married woman domiciled in England. She agreed, in terms of a deed executed in England, to mortgage or transfer to the appellant, the Bank of Africa, certain land that she owned in Johannesburg, Transvaal, South Africa. The title deeds of the property were already in the possession of the bank, which held it in safe custody. The purpose of the mortgage (or transfer) was security for advances made or to be made by the bank to $\mathrm{Mr}$ Cohen (the respondent's husband). She was, in terms of the agreement, free from any personal liability. She conferred power of attorney to Mr Wight, the bank's manager at the Johannesburg branch, who was responsible for arranging all the necessary instruments for this purpose and affecting the actual transfer. However, the bank was refused the registration of the property by the Land Registry because the mentioned deed was invalid and ineffectual in terms of the law of the Transvaal. The reason for this was that a married woman lacked the capacity to be bound as a surety for her husband, "even when she executes the deed by her own hand". ${ }^{6}$ The court thus had to pronounce on the contractual capacity of Mrs Cohen in respect of the immovable property in Johannesburg and address the issue of whether the bank had a right to possess the title deeds.

The court commenced by stating the general rule that "in regard to immovable property the lex situs, or, as it is sometimes styled, the lex rei sitae, prevails in respect to all rights, interests, and titles in and to such property" ${ }^{87}$ It accordingly applied the lex situs and arrived at the conclusion that the instrument of suretyship (the deed) was void due to the incapacity of one of the parties and therefore invalid against the respondent. The bank consequently could not hold Mrs Cohen liable on the deed. In respect of the title deeds, the court held that the bank did not hold them as mere custodians but by virtue of the agreement contained in the mentioned deed. The latter, as established in casu, was void and the right which the bank had to retain the deeds against the will of the defendant had ceased to exist.

This decision is, however, subject to considerable criticism. Clarkson and $\mathrm{Hill}^{88}$ submit that there are no apparent reasons for applying a different rule

84 Hill and Chong International Commercial Disputes. Commercial Conflict of Laws in English Courts 551.

85 [1909] 2 Ch 129.

86 Bank of Africa, Limited v Cohen supra 145.

87 Bank of Africa, Limited $v$ Cohen supra 146.

88 Clarkson and Hill The Conflict of Laws 476. 
for capacity to conclude a contract relating to immovables than the rule applied in respect of any other contract. According to the authors, the contract was most closely connected to the law of England, ${ }^{89}$ which should have been applied in casu as the proper law of the contract instead of the lex situs. If the proper law was applied, Mrs Cohen would have had the capacity to conclude the contract of suretyship. ${ }^{90}$

Rogerson concurs with Clarkson and Hill regarding the submission that English law (the proper law) should have been applied, but adds that Mrs Cohen should have been liable for damages due to a breach of contract. ${ }^{91}$ The case, according to the author, concerned a transfer contract which is governed by its own applicable law. This law is determined (as it is with other contracts) by ascertaining the law of the country with which the contract has its closest connection. ${ }^{92}$ In this context, the presumption is employed that the lex situs is the applicable law. ${ }^{93}$ However, the presumption can be rebutted. ${ }^{94}$ The author implies that this case presented the circumstances that would warrant such a rebuttal.

Dicey, Morris and Collins inter alia submit the following in respect of the decision:

(a) The court was not dealing with a mortgage but a contract to create one. It was generally accepted that contracts involving immovable property were governed by their proper law, usually, but not necessarily, the lex situs. However, the court made no attempt to determine the proper law of the contract. ${ }^{95}$

(b) The court omitted to ascertain the rules applicable in the Transvaal or how the Transvaal courts would have addressed the matter. It may for instance have discovered that the law of the Transvaal did not apply to a contract concluded in England by a woman domiciled there. In that case, the court should have applied domestic English law, the law which the lex situs would have applied. ${ }^{96}$ The authors seem to suggest that the court should have considered the application of renvoi in this context.

O'Brien agrees with the other authors that English law should have been applied and provides the following critique of the decision:

(a) the decision serves as authority for the faulty proposition that the capacity to conclude a contract involving foreign immovables and the capacity to transfer are governed by the lex situs;

89 The country where the defendant was both domiciled and resident.

90 Clarkson and Hill The Conflict of Laws 476.

91 Rogerson Collier's Conflict of Laws 384.

92 The author refers to art 3 of the Rome Convention (fn 27 above). See, for today, art 3 of the Rome I Regulation (fn 28 above).

93 The author refers to art 4(3) of the Rome Convention (fn 27 above). See, for today, art 4(1)(c) of the Rome I Regulation (fn 28 above).

94 Rogerson Collier's Conflict of Laws 384-385.

95 Collins et al Dicey, Morris and Collins on the Conflict of Laws 15ed 1333.

96 Ibid. 
(b) the case actually concerned contractual obligations and not conveyance (read: the creation of a limited real right per se), ${ }^{97}$ therefore the relevant legal system should have been the proper law of the contract;

(c) the decision was based on statements in an older edition of Dicey, ${ }^{98}$ which was criticised by Westlake ${ }^{99}$ as failing to draw a clear distinction between capacity to contract and the capacity to transfer;

(d) with regard to American law, the authorities were moving toward applying the lex loci contractus to capacity in respect of contracts involving foreign immovable property;

(e) Transvaal law probably had no interest in protecting a married woman not domiciled there;

(f) an action for damages should nevertheless have succeeded despite Transvaal law hindering an order for specific performance;

(g) there should have been a clear distinction between contractual rights and proprietary rights in casu;

(h) the court should have enforced the contractual obligation since the defendant was capable of effecting the transfer and had unconditionally undertaken to do so; and

(i) the case did not concern capacity at all: Transvaal law at the time stipulated certain formalities but it did not create any incapacities. ${ }^{100}$

\section{Summary}

There are only eight prominent English cases focussing specifically on contractual capacity. In respect of contracts relating to immovable property, the decision in Bank of Africa, Limited $v$ Cohen ${ }^{101}$ indicates that the lex situs should be applied. The position is not that obvious with regard to other contracts. In Sottomayor $v$ De Barros (1), ${ }^{102}$ Cooper $v$ Cooper ${ }^{103}$ and Baindail $v$ Baindail, ${ }^{104}$ which concerned the capacity to marry or to conclude an antenuptial contract, ${ }^{105}$ the courts applied the lex domicilii, while in Sottomayor $v$ De Barros (2) ${ }^{106}$ (on the capacity to marry) the court applied the lex loci contractus. The court also applied this legal system in Male $v$ Roberts, ${ }^{107}$ which related to a loan agreement. In Republica De Guatemala v Nunez, ${ }^{108}$ which concerned a contract of cession, the court refrained from

97 Contra Rogerson Collier's Conflict of Laws 384-385. Cf Cheng The Rules of Private International Law Determining Capacity 77.

98 The author probably refers to Dicey The Conflict of Laws 2ed (1908).

99 The author probably refers to Westlake Treatise on Private International Law 4ed (1905).

100 O'Brien Smith's Conflict of Laws 552-553. The author also submits that the decision was lacking parity with the earlier case of Re Courteney ex P Pollard (1840) Mont and Ch 239, which did not concern incapacity.

101 Supra.

102 Supra.

103 Supra.

104 Supra.

105 See par 21111 as to why these cases are discussed, although they do not concern commercial contracts.

106 Supra the remittance of Sottomayor v De Barros (1) supra from the Court of Appeal.

107 Supra.

108 Supra. 
indicating the legal system that should apply to the capacity of a minor to benefit from a contract of cession as the lex domicilii and the lex loci contractus coincided. In the most recent case, The Bodley Head Ltd $v$ Flegon, ${ }^{109}$ which related to a contract of agency, the court decided that contractual capacity should be governed by the putative objective proper law of the contract.

\section{The authors}

\section{Briggs}

According to Briggs, the English common law finds capacity to be present if it exists in terms of the personal law (the law of domicile) or the law governing the contract. ${ }^{110}$ The lex situs (usually) governs contractual capacity in respect of immovable property. ${ }^{111}$ The law of domicile governs the capacity to conclude a matrimonial contract. ${ }^{12}$

The author is in favour of the application of the law governing the contract $^{113}$ rather than the law of domicile. There may be no "reason or opportunity to know that the other may be domiciled in a state according to the law of which he has an unsuspected incapacity". ${ }^{114}$ In addition, someone's domicile cannot always readily be determined as "the detailed rules of the common law of domicile are far from being transparent in their application". ${ }^{115}$ However, the law of domicile should govern the capacity to conclude a matrimonial contract ${ }^{116}$ as "the personal law is obviously more appropriate" in this context. ${ }^{117}$ The proper law of the contract should today be determined in accordance with the Rome I Regulation. ${ }^{18}$

The author argues that the proper law should in this regard include a choice of law by the parties, ${ }^{19}$ as the chosen law could just as easily invalidate a contract or could even have, for instance, a higher age of majority ${ }^{120}$ However, a chosen law could be excluded on the basis of public policy.

109 [1972] 1 WLR 680.

110 Briggs Private International Law in English Courts (2014) 583 and 596. Cf Briggs The Conflict of Laws 2ed (2008) 165 and Briggs Private International Law in English Courts 615-616 and 948-949. According to the author (Briggs: Private International Law in English Courts $583 \mathrm{fn} 215$ ), the law governing the contract was previously the law of the place where the contract was made.

111 Briggs Private International Law in English Courts 583: "Where, however, the contract is for the disposition of land, the capacity rules of the lex situs may not be easily avoided."

112 Briggs Private International Law in English Courts 584, 616, 778 and 948.

113 Briggs Private International Law in English Courts 583, 615-616 and 948-949; cf 596.

114 Briggs Private International Law in English Courts 948.

115 Ibid.

116 Briggs Private International Law in English Courts 584, 616, 778 and 948.

117 Briggs Private International Law in English Courts 616.

118 See fn 28 above. Briggs Private International Law in English Courts 596; cf 948.

119 Briggs Private International Law in English Courts 583, 596, 615-616 and 948-949.

120 Briggs Private International Law in English Courts 949.

121 Briggs Private International Law in English Courts 583, 615-616 and 949. Cf Briggs Private International Law in English Courts 596: "In some cases the proposition that a would-be contracting party has found a path to the conclusion that he has contractual capacity is 


\section{Carter}

According to Carter, contractual capacity in an English context should in principle be governed by the proper law of the contract, objectively ascertained. ${ }^{122}$ The proper law, in this regard, should not be determined subjectively as this would enable a contractant to choose a more favourable legal system. ${ }^{123}$ The author rejects the application of the lex loci contractus to determine contractual capacity because the locus contractus may be fortuitous, contrived or unknown. Although the locus contractus is usually the place in which the last event necessary for the formation of the contract occurred, this cannot justify why the lex loci contractus should receive preference to govern an individual's capacity. ${ }^{124}$

The author clearly doubts the applicability of the lex domicilii on its own. In fact, in respect of the latter, he submits: "Sweeping dicta to the effect that the law of a party's domicil per se governs contractual capacity are unsupportable." ${ }^{\prime 25}$ A foreign contractant should not be allowed to rely on incapacity according to the lex domicilii to avoid liability. It does not follow, however, that a contractant who is capable in terms of the lex domicilii should be able to avoid liability because of incapacity according to the proper law of the contract. Therefore, any contractant may for enabling purposes be allowed to rely on the capacity of the other party in terms of the lex domicilii. ${ }^{126}$ This legal system is accepted to be the governing law in England in terms of Rule 182 of Dicey and Morris ${ }^{127}$ (the predecessor of Rule 228(1) of Dicey, Morris and Collins), ${ }^{128}$ at least if domicile is coupled with residence. ${ }^{129}$ In effect, Carter's view comes down to support for the alternative application of the proper law of the contract and the lex domicilii.

\section{Clarence Smith}

According to Clarence Smith, the lex domicilii (in principle) applies to contractual capacity. ${ }^{130}$ The lex loci contractus applies if the capable contractant could not reasonably be expected to know that the counterpart was incapable according to his or her lex domicilii. ${ }^{131}$ This means that the

unobjectionable; in others, the allegation that he has 'conferred capacity upon himself' betrays a respectable objection. A uniform solution to the problem may never be found, but it is certainly not to hand at the moment."

122 Carter 198757 British Yearbook of International Law 24.

123 Ibid.

124 Carter 198757 British Yearbook of International Law 25.

125 Carter 198757 British Yearbook of International Law $24 \mathrm{fn} 98$. The dicta referred to here relate to Sottomayor v De Barros (1) supra and Cooper v Cooper supra. Also see Cheng The Rules of Private International Law Determining Capacity 62-63 and 68.

${ }^{126}$ Carter 198757 British Yearbook of International Law 24.

127 Collins et al (eds) Dicey, Morris and Collins on the Conflict of Laws 11ed (1987) 1202.

128 Collins et al Dicey, Morris and Collins on the Conflict of Laws 15ed 1865.

${ }^{129}$ Carter 198757 British Yearbook of International Law 24.

130 Smith "Capacity in the Conflict of Laws: a Comparative Study" 19521 International and Comparative Law Quarterly 446470.

131 The author states at 470: "What is reasonable varies with the transaction, but extreme examples are that a tradesman supplying without extravagance a foreigner resident in the tradesman's country need not even inquire, while a banker accepting a guarantee from a 
author regards the lex domicilii as the default legal system; the lex loci contractus will, however, apply in addition where no fault was present on the part of the contract assertor. The author's approach closely resembles that found in most jurisdictions with codified rules in respect of contractual capacity, where the personal law applies in principle but in conjunction with the lex loci contractus if certain conditions are satisfied. ${ }^{132}$ The only condition to be complied with, according to the author's approach, is the absence of fault on the part of the contract assertor. The absence of fault thus plays the role of a requirement to be satisfied for the lex loci contractus to be applied, a structure referred to elsewhere in this study as the two-step model. ${ }^{13}$ The first step in terms of this model is the default employment of the primary applicable legal system, in casu, the lex domicilii. Step two: the lex loci contractus applies in addition to the default system where fault is absent on the part of the contract assertor. It may be noted that Clarence Smith's approach is specifically comparable to Article 17 of the Romanian Private International Law Code in that, in this jurisdiction, the absence of fault on the part of the contract assertor is the only requirement to be fulfilled for the lex loci contractus to apply in addition to the default legal system. ${ }^{134}$ Contractual capacity in respect of immovable property, according to the author, is governed by the lex situs. ${ }^{135}$

\section{Clarkson and Hill}

The authors support Rule 209 of Dicey, Morris and Collins ${ }^{136}$ to the effect that a contractant to an international contract should be regarded as having capacity if he has such by either the personal law or the objective proper law. In their opinion, therefore, a contractant incapable in terms of the proper law of the contract should nevertheless be liable if he or she has capacity according to (for instance) ${ }^{137}$ the lex domicilii. ${ }^{138}$ The rule, so they aver, is based on the protection of the incapable party and the law of the country of which this individual is a domiciliary ${ }^{139}$ is most suited to establish whether he

young person or married woman must inquire carefully and will be excused only if his enquiries are met with plausible lies. Where the parties are acquainted, and the contract purely personal, nothing at all will excuse ignorance."

132 There are four different conditions which may be set in this regard. See the discussion in Fredericks Contractual Capacity in Private International Law 166.

133 This model is discussed in detail in Fredericks Contractual Capacity in Private International Law 167.

134 Romanian Private International Law Code (1992) ch II, art 17. Regard may also be had to the Estonian Private International Law Act (2002) § 12(3); the Civil Code of the Republic of Lithuania (2000) ch 2, art 1.17(1); the Civil Code of the Russian Federation (2001) ch 67, art 1197(2); and the Private International Law Code (Tunisia) (1998) art 40, but in these jurisdictions, the formulation of the rule veers towards the three-step model. See the discussion in Fredericks Contractual Capacity in Private International Law 166-171.

135 Smith 19521 International and Comparative Law Quarterly 471.

136 Collins et al Dicey, Morris and Collins on the Conflict of Laws 14ed 1621. Rule 228 is of course the most recent in this regard (Collins et al Dicey, Morris and Collins on the Conflict of Laws 15ed 1865).

137 Dicey, Morris and Collins also refer to the law of residence as personal law (Collins et al Dicey, Morris and Collins on the Conflict of Laws 14ed 1621 and 1624).

138 Collins et al Dicey, Morris and Collins on the Conflict of Laws 14ed 1624.

139 The authors use the word "national" in this context but, as they support Dicey, Morris and Collin's rule, this should be read as "domiciliary". 
or she requires such protection. It follows that an individual who possesses capacity in terms of the lex domicilii should not be able to avoid liability by referring to another legal system. ${ }^{140}$ If a contractant were to be allowed to rely on incapacity in terms of the lex domicilii, it would be unfair to the counterpart who may have no reason to assume that the former has a foreign domicile, let alone possess knowledge of that country's capacity rules. In the same way, where contractants have capacity according to the proper law, it would be unreasonable for one of them to escape liability by relying on incapacity in terms of the personal law. ${ }^{14}$

The proper law referred to here is objectively ascertained, namely, the law of the country with which the contract is most closely connected. The proper law should not be subjectively determined, as this would enable a contractant to confer capacity upon him or her by merely agreeing to a contractual clause which selects a legal system under which he or she possesses capacity. ${ }^{142}$

Lastly, the authors confirm that the capacity to transfer immovable property (or to take such a transfer) is (in general) governed by the lex situs. ${ }^{143}$ English courts will usually not have jurisdiction in cases where questions concerning the law governing the transfer of foreign immovables arise. In this regard, a distinction should be drawn between the transfer of title and a contract in pursuance of which title has been transferred. An English court may indeed assume jurisdiction over disputes arising out of such a contract. Issues concerning the contract (including capacity) should be governed by the proper law of the contract which may or may not be the lex situs. This is the correct approach, according to the authors, because there is no apparent reason why the private international law rules for capacity to conclude a contract involving immovables should be different from those concerning any other contract. ${ }^{94}$ The law governing the question should be the law of the country with which the contract is most closely connected - the proper law of the contract. ${ }^{145}$

\section{Rogerson}

Rogerson submits that problems relating to contractual capacity in an English context hardly occur, since the only categories of individuals having limited capacity would be mental patients, intoxicated persons and minors. ${ }^{14}$ The author does not seem to take the possibility into account that foreign law may apply to contractual capacity. She also does not take incapacity due to the absence of spousal consent into consideration.

140 Clarkson and Hill The Conflict of Laws 250.

141 Ibid.

142 Ibid.

143 Clarkson and Hill The Conflict of Laws 474.

144 With specific reference to Bank of Africa, Limited $v$ Cohen supra.

145 Clarkson and Hill The Conflict of Laws 475-476.

146 Rogerson Collier's Conflict of Laws 320 . Fewer minors will be incapable especially since the age of majority in terms of $s 1$ of the Family Law Reform Act of 1969 has been reduced from twenty-one to eighteen. 
When problems do occur, however, the governing law may be the lex domicilii, the lex loci contractus or the proper law of the contract. Neither the lex domicilii nor the lex loci contractus are preferred because an application of the former may work unjustly toward the counterpart and the locus contractus may be fortuitous. ${ }^{14}$ The most appropriate governing law, according to the author, is the proper law of the contract. ${ }^{148}$ In this context, reference is made to the putative proper law which refers to "the applicable law ascertained by looking for the system of law with which the transaction has its closest and most significant connection. Any express choice of law should be ignored, at any rate if that law was chosen in order to confer capacity which otherwise would not exist". ${ }^{149}$ It therefore perhaps remains possible to take the subjective proper law into account if it were not chosen in order to confer capacity. The author only refers to an express choice of law; the result then is that a tacit choice of law may indeed confer capacity which would not otherwise exist.

Finally, with reference to Bank of Africa, Limited $v$ Cohen, ${ }^{150}$ the author states that it appears that the lex situs governs not only the capacity to convey or to create an interest in land, but also the capacity to conclude a contract in this regard. ${ }^{15}$

\section{Dicey, Morris and Collins}

Contractual capacity is governed by Rule 228 enunciated by the authors. ${ }^{152}$ The rule reads as follows:

"(1) The capacity of an individual to enter into a contract is governed by the law of the country with which the contract is most closely connected or by the law of his domicile and residence:

(a) If he has capacity to contract by the law of the country with which the contract is most closely connected, the contract will (semble) be valid so far as capacity is concerned.

(b) If he has capacity to contract by the law of his domicile and residence, the contract will (semble) be valid so far as capacity is concerned.

(2) If the contract is concluded between persons who are in the same country, an individual may not rely on his incapacity under the law of some other country with which the contract is most closely connected or in which he is domiciled and resident, unless the other party was aware of the incapacity at the time of the conclusion of the contract, or was not aware thereof as a result of negligence."

Clause (1) of the rule thus states that the contractual capacity of an individual shall be governed by both the proper law of the contract and his or

147 Rogerson Collier's Conflict of Laws 320.

148 Rogerson Collier's Conflict of Laws 321. In the previous edition (Collier Conflict of Laws (2001) 210), reference was made to the Canadian decision Charron v Montreal Trust Co (1958) 15 DLR (2d) 240 (Ontario) in support of this submission and to further state that cases previously referred to are consistent with this governing law because the law of the place of contracting and the proper law were the same.

149 Rogerson Collier's Conflict of Laws 321.

150 Supra.

151 Rogerson Collier's Conflict of Laws 384-385.

152 Collins et al Dicey, Morris and Collins on the Conflict of Laws 15ed 1865. 
her personal law (domicile and residence). Clause (a) further explains that if a contractant who is incapable in terms of the personal law possesses capacity according to the proper law of the contract, then the contract will nevertheless be valid. Clause (b) covers the inverse situation as it provides that the contract will be valid where the contractant in question lacked capacity in terms of the proper law of the contract but possessed such according to the personal law.

The authors refer to the law of domicile and residence. ${ }^{154}$ It is not clear whether either of these will suffice or whether capacity under both the law of domicile and the law of residence is required. The authors do not discuss this issue. The use of the word "and" seems to suggest that the latter possibly was intended. However, the authors also refer to the "personal law" as an applicable legal system. ${ }^{155}$ Here it seems that the authors had in mind that one can have capacity in terms of either the law of domicile or the law of residence. If the lex domicilii and the law of residence were meant to apply in the alternative, the word "or" should have been used.

Clause (2) is intended to give effect to Article 13 of the Rome I Regulation (Article 11 of the Rome Convention) on the assumption that clause (1) correctly sets out the position in English law. ${ }^{156}$ This clause therefore means that a contractant incapable in terms of the proper law of the contract or the personal law shall not be able to rely on this incapacity if the contract was concluded between the contractants in the same country, unless the counterpart knew or should have known about the incapacity. Clause (2) implies that the lex loci contractus applies as an additional legal system if the parties were in the same country at the conclusion of the contract. ${ }^{157}$ Here it must be indicated that the authors follow the system which will be named the three-step model in respect of fault. ${ }^{158}$ Step 1: the prima facie applicable legal systems are the objective proper law and the personal law. Step 2: the lex loci contractus is added to these legal systems if the parties were present in the same country at the time of the conclusion of the contract. Step 3: the lex loci contractus is not applicable if fault was present on the part of the contract-assertor in that he or she was aware of the incapacity at the time of the conclusion of the contract, or was not aware thereof as a result of negligence.

The authors clearly reject the possibility of the exclusive application of the lex domicilii to capacity. They correctly indicate that this legal system was adhered to in case law that did not concern contractual capacity in the usual

153 The main consideration with this rule is the protection of the incapable contractant under his or her personal law (Collins et al Dicey, Morris and Collins on the Conflict of Laws 15ed 1869).

154 In terms of Rule 228(1).

155 Collins et al Dicey, Morris and Collins on the Conflict of Laws 15ed 1870.

156 The authors expressly refer to art 13 of the Rome I Regulation but continue to discuss the contents of art 11 of the Rome Convention. This, according to the current author, is an error as the authors intended to discuss art 13 (Rome I Regulation). This seems to be an editorial oversight.

157 Art 11 of the Rome Convention and art 13 of the Rome I Regulation are discussed in detail in Fredericks Contractual Capacity in Private International Law 179-189 and Fredericks 2018 SA Merc LJ (forthcoming).

158 As discussed in detail in Fredericks Contractual Capacity in Private International Law 167. 
sense. ${ }^{159}$ The lex domicilii cannot universally apply to contractual capacity in respect of commercial contracts, to the capacity to marry and to contractual capacity in respect of antenuptial contracts. Great inconvenience and injustice would arise if the lex domicilii were applied in international transactions. A contractant would be entitled to escape liability simply because of incapacity by the law of domicile which may be unknown to the counterpart. ${ }^{100}$

The lex loci contractus, the authors continue, plays a prominent role in civil law countries (in addition to the personal law) in respect of contractual capacity. ${ }^{161}$ While this legal system has gained some support in England, ${ }^{162}$ Scotland, ${ }^{163}$ South Africa ${ }^{64}$ and Canada (Saskatchewan), ${ }^{165}$ objections may be raised against it. The place where the contract is made could be entirely fortuitous, especially in matters involving letters, telex, fax or telephone (one could add: electronic communications) ${ }^{966}$ The law under which, and not the place at which, the contract was made ${ }^{167}$ should be decisive. The proper law is therefore included in the list of alternatively applicable legal systems but the lex loci contractus only for the scenario that the parties are in the same country at the moment of conclusion of the contract - and then only by implication.

The authors believe that a contractant should not be able to confer capacity upon him- or herself by simply agreeing to the choice of a system of law as the law of the contract. They are therefore in favour of the application of the legal system with which the contract is most closely connected, that is, the proper law objectively determined. ${ }^{168}$

Capacity in respect of immovable property is governed by Rule 132(1) enunciated by the authors. ${ }^{169}$ The rule states: "A person's capacity to alienate an immovable by sale or mortgage inter vivos is governed by the lex situs." ${ }^{\text {"70 }}$ The lex situs also governs the capacity to acquire immovable property. ${ }^{171}$

The authors are therefore in favour of the alternative application of the objective proper law of the contract, the law of domicile and residence and,

159 Cases such as Sottomayor v De Barros (1) supra and Cooper v Cooper supra concerned the capacity to marry and to conclude an antenuptial agreement. Also see the discussion of these cases at 21112 and 21113 . See further Cheng The Rules of Private International Law Determining Capacity 62-63.

160 Collins et al Dicey, Morris and Collins on the Conflict of Laws 15ed 1867. Also see Cheng The Rules of Private International Law Determining Capacity 68.

161 The authors refer to the position in France and Germany in this regard. See, in particular, Collins et al Dicey, Morris and Collins on the Conflict of Laws $15 \mathrm{ed} 1868 \mathrm{fn} 553$ and 554.

162 Male $v$ Roberts supra.

163 McFeetridge $v$ Stewarts and Lloyds Ltd 1913 SC 773

164 Kent $v$ Salmon supra.

165 Bondholders Securities Corporation v Manville [1933] 4 DLR 699; [1933] 3 WWR 1.

166 Collins et al Dicey, Morris and Collins on the Conflict of Laws 15ed 1868.

167 lbid.

168 Collins et al Dicey, Morris and Collins on the Conflict of Laws 15ed 1869.

169 Collins et al Dicey, Morris and Collins on the Conflict of Laws 15ed 1332.

170 lbid

171 Collins et al Dicey, Morris and Collins on the Conflict of Laws 15ed 1333. 
in particular circumstances, the lex loci contractus. ${ }^{172}$ With regard to immovable property, capacity is governed by the lex situs.

\section{Fawcett and Carruthers}

The authors submit that the lex domicilii is an unsatisfactory test regarding contractual capacity, considering the unfairness that it may yield in commercial interaction. ${ }^{173}$ The exclusive application of the lex loci contractus, according to the authors, is also untenable as it would enable a contractant to avoid incapacity in terms of the law that governs the contract by contracting in a country where the law is more favourable. Further, the lex loci contractus would be inadequate when parties contract in a country where they are only momentarily present. ${ }^{1 / 4}$

Modern authority, according to the authors, indicates that contractual capacity should be governed by the proper law of the contract objectively ascertained. This was indeed the position in the Canadian decision Charron $\checkmark$ Montreal Trust $\mathrm{Co}^{175}$ and the English case The Bodley Head Ltd $v$ Flegon. ${ }^{176}$ "The proper law" should be taken to mean the law of the country with which the contract is most closely connected. Intention does not play a role here. A contractant should not be able to confer capacity upon himself by submitting to a law factually unrelated to the contract. ${ }^{1 / 7}$

The authors therefore do not support the application of the lex domicilii or the exclusive application of the lex loci contractus to contractual capacity. In as far as the proper law of the contract should play a role, this should be the proper law objectively determined.

\section{Fawcett, Harris and Bridge}

The authors reject the exclusive application of the lex domicilii to commercial contracts because of the impractical results that would arise. ${ }^{178}$ The authors probably have the protection of local creditors in mind. The advantages of the proper law approach are that it may limit the evasion of capacity rules and that it ensures a strong connection between capacity and the contract itself. ${ }^{179}$

The current author agrees that the proper law approach is indeed more effective in preventing the evasion of capacity rules when compared to the

172 See Stone EU Private International Law 2ed (2010) 329 who supports this proposal by implication.

173 Fawcett and Carruthers Cheshire, North and Fawcett Private International Law 750. The authors believe that in civil-law systems a contractant may not rely on incapacity in terms of his personal law if he or she has such according to the lex loci contractus. The discussion in Fredericks Contractual Capacity in Private International Law 164-175 explains why this statement is inaccurate on various levels.

174 Fawcett and Carruthers Cheshire, North and Fawcett Private International Law 751.

175 Supra.

176 Supra.

177 Fawcett and Carruthers Cheshire, North and Fawcett Private International Law 751.

178 Fawcett et al International Sale of Goods 657.

179 Fawcett et al International Sale of Goods 658. 
application of the lex loci contractus. The parties could intentionally select a country of conclusion with the aim of evading another legal system (for instance, the incapable contractant's country of domicile). On the other hand, if the personal law (for instance the lex domicilii) were to be applied, evasion of capacity rules would even be more difficult.

However, the law of the closest connection may again, according to the authors, be difficult to determine and may lead to excessive uncertainty because the common law rules will have to be utilised to ascertain the applicable law rather than the provisions of Article 4 of the Rome Convention $^{180}$ (today Article 4 of the Rome I Regulation). ${ }^{18}$

The current author submits, however, that the provisions of the Rome Convention / Rome I Regulation should be utilised in determining the proper law applicable to contractual capacity. ${ }^{182}$ The authors seem to confuse the exclusion of capacity under the Rome Convention / Rome I Regulation ${ }^{183}$ with the non-applicability thereof in determining the proper law for the purposes of capacity. There seems to be no reason in logic or authority for the discontinued common-law rules on the determination of the proper law of contract to now suddenly be revived to determine the proper law in the context of capacity.

The authors are of the opinion that Rule 179(1) of Dicey and Morris ${ }^{184}$ (the predecessor of Rule 228(1) of Dicey, Morris and Collins) ${ }^{185}$ is commendable as it is inclined to uphold the contract; an individual need only have capacity by either the proper law or the personal law. However, the connecting factors (proper law, domicile, residence) are unfortunately, inherently uncertain and this will again undermine commercial certainty, especially since the court may now have to consider not one but two (or three) connecting factors. ${ }^{18}$

The authors therefore do not indicate clear support for any of the legal systems that are commonly utilised to determine contractual capacity.

\section{Hill and Chong}

Hill and Chong support Rule 209(1) of Dicey, Morris and Collins. ${ }^{187}$ In terms of this rule, a contractant should not be able to rely on incapacity in terms of any other law if he or she possesses capacity according to the proper law of

\footnotetext{
See fn 27 above.

See fn 28 above.

182 Also see Briggs Private International Law in English Courts 595; cf 948.

183 Art 1(2)(a) of the Rome Convention (fn 27 above); art 1(2)(a) of the Rome I Regulation (fn 28 above).

184 Collins et al (eds) Dicey, Morris and Collins on the Conflict of Laws 13ed (2000) 1271-1272.

185 Collins et al Dicey, Morris and Collins on the Conflict of Laws 15ed 1865.

186 Fawcett et al International Sale of Goods 658.

187 Collins et al Dicey, Morris and Collins on the Conflict of Laws 14ed 1621.
} 
the contract and does not require protection. ${ }^{188}$ The authors emphasise that the lex loci contractus is irrelevant in this context. ${ }^{189}$

The authors agree that the lex domicilii should not apply exclusively. The legitimacy of the argument against the exclusive application of the lex domicilii is illustrated in the following example: "[l]f ... an English resident, aged seventeen, contracts to buy a motor-car from a foreign seller, the contract would not be valid if contractual capacity were regarded as being a matter solely for the personal law." 190

The authors submit that an individual should be taken to have capacity if he or she has such according to the putative proper law. ${ }^{191}$ The proper law in this context, the authors continue, is the law with which the contract has its closest and most real connection and not the proper law chosen by the parties, whether expressly or impliedly. ${ }^{192}$ If the proper law was to be determined subjectively as opposed to objectively, an incapable individual would be able to confer capacity upon himself by merely electing a favourable legal system. This would frustrate the protective effect of the personal law.

\section{McClean and Beevers}

McClean and Beevers admit that it is rather difficult to state which legal system an English court would apply in cases involving contractual capacity. Generally, the authors submit, two approaches exist in this regard: the lex domicilii applies or the objective proper law governs. Application of the objective proper law (and not the subjective proper law or the lex loci contractus) is promoted as the latter approaches would enable an incapable individual to confer capacity upon him- or herself by a mere choice of law or the conclusion of the contract in a specific country. ${ }^{194}$ Although the application of lex domicilii is "old-fashioned", ${ }^{195}$ deciding between this legal system and the objective proper law of contract is rather complicated. The following scenario (and explanation) illustrates this: "A domiciled Ruritanian aged 20 buys goods on credit from a London shop. Could he refuse to pay

188 Hill and Chong International Commercial Disputes. Commercial Conflict of Laws in English Courts 550 .

189 Hill and Chong International Commercial Disputes. Commercial Conflict of Laws in English Courts 550. Of course, the lex loci contractus will play a role in terms of art 11 of the Rome Convention (fn 27 above) and art 13 of the Rome I Regulation (fn 28 above).

190 Hill and Chong International Commercial Disputes Commercial Conflict of Laws in English Courts 550 .

191 Hill and Chong International Commercial Disputes. Commercial Conflict of Laws in English Courts 550, with particular reference to Homestake Gold of Australia Ltd v Peninsula Gold Pty Ltd (1996) 20 ACSR 67.

192 Also see the discussion of The Bodley Head Ltd $v$ Flagon in par 21118 where, according to the authors, the court accepted that the putative proper law should be determined by reference to the law which the parties expressly or tacitly chose.

193 Hill and Chong International Commercial Disputes. Commercial Conflict of Laws in English Courts 551.

194 McClean and Beevers Morris The Conflict of Laws 386.

195 Ibid. 
for them on the ground that by Ruritanian law minority ends at 21 and contracts made by minors cannot be enforced against them?"196

If we assume that the contract was concluded inter praesentes in the London shop and the latter is English-owned and -managed, then, according to the author, English law would logically be the putative proper law of the contract. English law would therefore be applied as it would be unfair and inconvenient if the validity of this contract was dependant on the foreign domicile of the incapable party with which the counterpart could not be expected to be familiar. But if the contract was concluded via correspondence, the letter of acceptance was posted from Ruritania and the shop was owned and managed by Ruritanians, then, according to the authors, it would seem that Ruritanian law as the putative proper law should apply. ${ }^{197}$ The current author, however, suggests that English law would be the proper law also in the second scenario, as English law is the law of the country of the seller (the default proper law in terms of the Rome Convention and the Rome I Regulation). ${ }^{198}$

Turning to case law, the authors submit that, while there have been dicta favouring the lex domicilii, ${ }^{199}$ the lex loci contractus ${ }^{200}$ and the proper law of the contract, ${ }^{201}$ it is uncertain which route English courts will follow. The authors in final instance suggest that the best solution would be to regard a contractant as capable if he is such in terms of either the proper law of the contract or the personal law (domicile and residence). ${ }^{202}$

\section{O’Brien}

O'Brien is of the opinion that, while the personal law may be referred to for the capacity to marry or to make a will, it is not preferable as applicable law for the purposes of contractual capacity, especially not where the contract is concluded outside the domiciliary country. Although the lex loci contractus has been referred to previously in case law, ${ }^{203}$ it cannot be supported because it has no necessary connection with the parties or the substance of the contract. ${ }^{204}$ It could also be exploited by the stronger contractant who

196 Ibid.

197 Ibid.

198 See art 4(2) of the Rome Convention (fn 27 above) and art 4(1)(a) of the Rome I Regulation (fn 28 above).

199 Sottomayor $v$ De Barros (1) supra and Cooper $v$ Cooper supra. The authors imply that these cases concerned the capacity to marry and not contractual capacity and are therefore not genuine authority (McClean and Beevers Morris The Conflict of Laws $387 \mathrm{fn} \mathrm{177).}$

200 Male $v$ Roberts supra and Baindail v Baindail supra. But this legal system, the authors concede, may be fortuitous and is therefore of little importance (McClean and Beevers Morris The Conflict of Laws 387).

201 The Bodley Head Ltd v Flegon supra. See McClean and Beevers Morris The Conflict of Laws 387. Also see the discussion of the dicta in The Bodley Head Ltd $v$ Flegon supra 689 in par 21118 .

202 McClean and Beevers Morris The Conflict of Laws 388. This view is similar to Dicey, Morris and Collins' Rule 209 (Collins et al Dicey, Morris and Collins on the Conflict of Laws 14ed), but the authors do not refer to this source.

203 As in Male $v$ Roberts supra, according to the author.

204 O'Brien Smith's Conflict of Laws 318. 
may intentionally have the parties conclude a contract in a country where the protection of the counterpart, whose capacity is in doubt, is the weakest. ${ }^{205}$

The putative proper law may also find application. The author describes this legal system as "that which would be the applicable law of the contract if the capacity issue is determined affirmatively"206 or "that which would be the applicable law if the contract was not affected by the incapacity". ${ }^{207}$ The proper law can, however, be chosen by the parties. This would enable the stronger contractant to specify a law which may remove the protection which the vulnerable counterpart might have enjoyed. The most viable option, the author continues, is the putative proper law in the objective sense, notwithstanding its shortcoming, ${ }^{208}$ as it avoids both accident $^{209}$ and machination. ${ }^{210}$

The author confirms that, in general, the capacity to conclude contracts in respect of immovable property in the forum state is governed by the lex situs. ${ }^{21}$ This is not the position with regard to the capacity to conclude a contract involving foreign immovables. Based on the critique levelled against the decision in Bank of Africa, Limited $v$ Cohen, ${ }^{212}$ it is deduced that the author supports the application of the objective putative proper law in this regard. ${ }^{2}$

\section{Summary}

In summary, some English authors expressly reject the general application of the lex domicilii to contractual capacity ${ }^{214}$ while others reject its exclusive application. ${ }^{215}$ Authors such as Carter, ${ }^{216}$ Rogerson, ${ }^{217}$ Dicey, Morris and Collins, ${ }^{218}$ Hill and Chong, ${ }^{219}$ McClean and Beevers ${ }^{220}$ and O'Brien ${ }^{221}$ reject

205 O'Brien Smith's Conflict of Laws 319.

206 O'Brien Smith's Conflict of Laws 318.

207 O'Brien Smith's Conflict of Laws 319.

208 Namely, that it does not ensure the protection of the vulnerable contractant as a reference to his or her personal law might have.

209 Here the author probably refers to the application of the lex loci contractus.

210 O'Brien Smith's Conflict of Laws 319. Here the author probably refers to the application of the lex domicilii.

211 O'Brien Smith's Conflict of Laws 551.

212 Supra. See fn 96-100.

213 O'Brien Smith's Conflict of Laws 551-552.

214 Briggs Private International Law in English Courts 948 (the lex domicilii, according to the author (at 616), is however, more appropriate in respect of matrimonial contracts); Carter 198757 British Yearbook of International Law 24 (the author, however, asserts that the lex domicilii can be relied upon for enabling purposes); McClean and Beevers Morris The Conflict of Laws 386; O'Brien Smith's Conflict of Laws 318; and Rogerson Collier's Conflict of Laws 320.

215 Briggs The Conflict of Laws 165; Clarkson and Hill The Conflict of Laws 250; Collins et al Dicey, Morris and Collins on the Conflict of Laws 15ed 1867; Fawcett and Carruthers Cheshire, North and Fawcett Private International Law 750; Fawcett et al International Sale of Goods 657; and Hill and Chong International Commercial Disputes. Commercial Conflict of Laws in English Courts 550. Also see Cheng The Rules of Private International Law Determining Capacity 62-63 and 72.

216 Carter 198757 British Yearbook of International Law 25.

217 Rogerson Collier's Conflict of Laws 320.

218 Collins et al Dicey, Morris and Collins on the Conflict of Laws 15ed 1868. 
the application of the lex loci contractus in general. Fawcett and Carruthers, ${ }^{222}$ on the other hand, only reject the exclusive application of this legal system. Dicey, Morris and Collins ${ }^{223}$ add the lex loci contractus to the objective proper law and the personal law (law of domicile and habitual residence), for the scenario that the parties were present in the same country at the time of the conclusion of the contract. However, the lex loci contractus is not applicable if fault was present on the part of the contract assertor in that he or she was aware of the incapacity at the time of the conclusion of the contract, or was not aware thereof as a result of negligence. ${ }^{224}$ Clarence Smith ${ }^{225}$ is of the opinion that the lex loci contractus should only be applicable (that is: in addition to the lex domicilii) if no fault was present on the part of the contract assertor in that he or she did not know and could not reasonably be expected to know that the counterpart was incapable according to his or her lex domicilii. ${ }^{226}$

In as far as the proper law of contract plays a role in contractual capacity, a number of authors reject the application of this legal system subjectively ascertained. $^{227}$ Rogerson $^{228}$ would consider the subjective proper law, ${ }^{229}$ provided that it is not chosen in order to confer capacity. There is some support for the proper law of contract objectively ascertained. ${ }^{230}$ Most of the authors, however, refer to the more technically correct putative objective proper law of the contract. ${ }^{231}$ Fawcett, Harris and Bridge ${ }^{232}$ expressly reject the exclusive application of the proper law in general while O'Brien ${ }^{233}$ rejects the application of the putative proper law subjectively determined.

219 Hill and Chong International Commercial Disputes. Commercial Conflict of Laws in English Courts 550 .

220 McClean and Beevers Morris The Conflict of Laws 386.

221 O'Brien Smith's Conflict of Laws 318-319.

${ }^{222}$ Fawcett and Carruthers Cheshire, North and Fawcett Private International Law 751.

${ }^{223}$ Collins et al Dicey, Morris and Collins on the Conflict of Laws 15ed 1865.

224 Ibid.

225 Smith 19521 International and Comparative Law Quarterly 470.

226 Also see Cheng The Rules of Private International Law Determining Capacity 71 and 128 in this regard who submits that the capacity to conclude a contract of a business nature (not relating to immovables) should, in addition to the lex domicilii, be governed by the lex loci contractus.

227 Carter 198757 British Yearbook of International Law 24; Clarkson and Hill The Conflict of Laws 250; Collins et al Dicey, Morris and Collins on the Conflict of Laws 15ed 1869; Fawcett and Carruthers Cheshire, North and Fawcett Private International Law 751; and Hill and Chong International Commercial Disputes. Commercial Conflict of Laws in English Courts 551.

228 Rogerson Collier's Conflict of Laws 321.

229 Also see Briggs Private International Law in English Courts 583, 596, 615-616 and 948-949. The proper law subjectively ascertained could, according to the author, be excluded on the basis of public policy.

${ }^{230}$ Carter 198757 British Yearbook of International Law 24; Clarkson and Hill The Conflict of Laws 250; and Collins et al Dicey, Morris and Collins on the Conflict of Laws 15ed 869.

231 Hill and Chong International Commercial Disputes. Commercial Conflict of Laws in English Courts 551; McClean and Beevers Morris The Conflict of Laws 386; O'Brien Smith's Conflict of Laws 319; and Rogerson Collier's Conflict of Laws 321.

${ }^{232}$ Fawcett et al International Sale of Goods 658.

233 O'Brien Smith's Conflict of Laws 318-319. 
In respect of these English authors that indeed support a specific proposal with regard to contractual capacity in private international law, ${ }^{234}$ the majority seems in favour of the alternative reference rule advocated by Dicey, Morris and Collins. According to the authors, contractual capacity should be governed by the objective proper law of the contract or the lex domicilii and the law of residence. ${ }^{235}$ Authors such as Clarkson and Hill, ${ }^{236}$ Hill and Chong ${ }^{237}$ and McClean and Beevers ${ }^{238}$ clearly support this proposal while Carter $^{239}$ and Fawcett, Harris and Bridge ${ }^{240}$ acknowledge its tenability but refrain from expressing support.

In respect of contractual capacity in as far as immovable property is concerned, Briggs, ${ }^{241}$ Clarence Smith, ${ }^{242}$ Rogerson, ${ }^{243}$ and Dicey, Morris and Collins ${ }^{244}$ express support for the application of the lex situs. ${ }^{245}$ Clarkson and Hill $^{246}$ and O'Brien ${ }^{247}$ agree with this view only in respect of local immovable property; the capacity to conclude contracts involving foreign immovables should be governed by the objective (putative) proper law. ${ }^{24}$

\section{Scotland}

Some uncertainty exists in respect of the law applicable to contractual capacity in Scottish private international law. The choice, however, lies between the lex domicilii, the lex loci contractus and the proper law of the contract. Some support also exists for the application of the lex situs in contracts involving immovable property.

234 Fawcett and Carruthers Cheshire, North and Fawcett Private International Law, as well as Fawcett et al International Sale of Goods, do not express clear support for any of the legal systems to govern capacity.

235 Collins et al Dicey, Morris and Collins on the Conflict of Laws 15ed 1865 (Rule 228).

236 Clarkson and Hill The Conflict of Laws 250.

237 Hill and Chong International Commercial Disputes. Commercial Conflict of Laws in English Courts 550 .

238 McClean and Beevers Morris The Conflict of Laws 388.

239 Carter 198757 British Yearbook of International Law 24

240 Fawcett et al International Sale of Goods 658. Also see their critique against this rule (at 658).

241 Briggs Private International Law in English Courts 583.

242 Smith 19521 International and Comparative Law Quarterly 471.

243 Rogerson Collier's Conflict of Laws 384-385.

244 Collins et al Dicey, Morris and Collins on the Conflict of Laws 15ed 1332-1333.

245 But see Cheng The Rules of Private International Law Determining Capacity 75-82 and 128 who maintains that, while popular opinion favours the application of the lex situs to contractual capacity in respect of immovable property, this issue should be governed by the lex domicilii.

246 Clarkson and Hill The Conflict of Laws 474.

247 O'Brien Smith's Conflict of Laws 551.

248 Clarkson and Hill The Conflict of Laws 475-476; and O'Brien Smith's Conflict of Laws 551-553. The only reason submitted for adopting such an approach is that there should be no difference between the choice of law rules for capacity to conclude contracts involving immovables and the rules for capacity to enter into any other type of contract. Of course, this does not justify a distinction between local and foreign immovable property. Also see Cheng The Rules of Private International Law Determining Capacity 75, 78-79 and 128. 


\section{The courts}

\section{Introduction}

According to Anton and Beaumont, the courts in Scotland draw a distinction between ordinary commercial (mercantile) contracts and other (nonmercantile) contracts. In respect of mercantile contracts, although the cases are sparse and the conflict rules regarding capacity inadequately addressed, they tend to indicate that the lex loci contractus must be applied. It seems likely, according to the authors, that the courts have accepted that an individual incapable in terms of his or her personal law may validly conclude mercantile contracts in a country where this incapacity was not applicable. ${ }^{249}$ The most prominent Scottish decision in this regard is McFeetridge $v$ Stewarts and Lloyds Ltd. ${ }^{250}$

\section{McFeetridge $v$ Stewarts and Lloyds Ltd ${ }^{251}$}

In casu, the appellant, McFeetridge, a minor with an Irish domicile, concluded a contract of employment with a Scottish company. He was injured in the course of his employment and agreed to accept compensation under the Workmen's Compensation Act, 1906, but this, it was averred, was done in ignorance of his common-law rights. After receiving compensation for some time, McFeetridge instituted a common-law action arguing that, since he lacked capacity under the lex domicilii, the agreement pertaining to his election of compensation was void.

The court rejected the incapacity argument and concluded that the lex loci contractus was applicable to the matter. Lord Salvesen decided: "In the case of a minor, the reasonable view seems to be that he should have such protection in respect of his minority as the country in which he contracts would extend to a native, but that he should have no higher or different right." ${ }^{252}$

The court thus clearly stated that the protection of a minor should be determined with reference to the lex loci contractus and not the lex domicilii. The court continued:

"The considerations which support this view are mainly those of good sense and expediency. A foreigner who contracts in Scotland with a native of that country must prima facie be held to intend that the law of Scotland shall be held to apply to the transaction. The Scottish contracting party cannot be presumed to know the law which regulates the capacity of the foreigner with whom he contracts. Indeed he has no reason to know that the foreigner has not become domiciled in Scotland; for if he is resident there this is a matter which may be known only to himself."

\footnotetext{
Anton and Beaumont Private International Law 276. 
From this dictum it is clear that, according to Lord Salvesen, contracts concluded in Scotland between foreign and local domiciliaries are to be governed by the lex loci contractus. The Scottish contractant need neither take cognisance of where the other party is domiciled nor of the personal law of the counterpart.

Anton and Beaumont point to the fact that, although the court explicitly proceeded from the view that the lex loci contractus governed the matter, this legal system was also the proper law of the contract and no choice had to be made between them. It should also be remembered that in 1913, when the case was decided, the lex loci actus was indeed often the proper law of the contract. ${ }^{254}$ Nevertheless, the case does contain clear support for the application of the lex loci contractus to contractual capacity.

\section{Obers $v$ Paton's Trustees ${ }^{255}$}

In a non-commercial context, the Scottish courts may apply the lex domicilii to capacity. ${ }^{256}$ In this regard, Anton and Beaumont ${ }^{257}$ discuss the decision in Obers $v$ Paton's Trustees. ${ }^{25}$

Mr Paton Jr, domiciled in Scotland, relocated to France and acquired a "trading domicile" there. Subsequent to his bankruptcy and sequestration according to French law, he returned to Scotland where he executed and registered a discharge of his legitim. ${ }^{259}$ His justification for this was that, during his father's lifetime, he (Mr Paton $\mathrm{Sr}$ ) had made various cash advances to Mr Paton Jr. He therefore believed that it was proper, in respect of these advances, to execute the discharge. ${ }^{260}$ Shortly afterwards, Mr Paton $\mathrm{Sr}$ died, leaving a will from which Mr Paton Jr accepted an alimentary provision only. A French official, representing the general body of creditors, instituted an action against Mr Paton $\mathrm{Jr}$ for the reversing of the discharge and the payment (to the creditors) of the legitim.

The Lord President held that, in terms of Scots law, an insolvent was incapable of waiving (discharging) his right to the legitimate portion of his father's estate. ${ }^{261}$ The insolvent was incapable because such a waiver would prejudice the creditors and amount to fraud. Therefore, although not expressly stated, the court applied Scots law, the lex domicilii (the domicile of the insolvent), to the issue of capacity, as the Lord President approached the matter from a Scots perspective.

254 Anton and Beaumont Private International Law 277-278.

255 (1897) 24 R 719. Also see De Virte v MacLeod (1869) 6 SLR 236, where the lex domicilii was applied.

256 Anton and Beaumont Private International Law 278-279.

257 Anton and Beaumont Private International Law 278.

258 Supra.

259 In Scots law this related to a child's legal share of his or her parents' moveable property on their death. See fn 48 for an explanation. See DSL http://www.dsl.ac.uk/entry/snd/legitim (accessed 2018-07-28).

260 Obers v Paton's Trustees supra 350.

261 Obers v Paton's Trustees supra 352. 


\section{Summary}

In summary, as illustrated in the prominent Scottish decisions, the courts seem inclined to apply the lex loci contractus to capacity in mercantile (commercial) contracts ${ }^{262}$ and the lex domicilii in respect of non-mercantile (non-commercial) contracts. ${ }^{263}$

\section{The authors}

\section{Anton and Beaumont}

Anton and Beaumont support the distinction in Scots case law between ordinary commercial contracts and non-mercantile contracts, the lex loci actus being applicable to the first and the lex domicilii to the second type of contract. $^{264}$ The authors have reservations about applying the objective proper law, as advocated by some of the English authors. ${ }^{265}$ According to the latter authors, the proper law has to be ascertained objectively, otherwise a minor may confer on him- or herself capacity which he or she otherwise would not have had by merely agreeing to the application of another legal system. Anton and Beaumont submit that the risk thereof is real, considering the pace at which international commerce is developing. The problem could, however, be addressed legislatively. In any event, the risk mentioned must be weighed against the uncertainty which such a rule would introduce in respect of ordinary business contracts, more particularly, ordinary contracts of sale, where the seller may also require protection. ${ }^{266}$

Finally, Anton and Beaumont submit that the capacity to hold immovable property or to alienate an immovable by way of sale, mortgage or donation, whether inter vivos or mortis causa, must be governed by the lex situs. ${ }^{267}$

\section{Crawford and Carruthers}

These authors do not expressly support any of the available legal systems but seem to endorse Cheshire's suggestions during his David Murray lecture

262 McFeetridge $v$ Stewarts and Lloyds Ltd supra.

263 See De Virte v MacLeod supra; and Obers v Paton's Trustees supra.

264 Anton and Beaumont Private International Law 276. Also see Beaumont and McEleavy Private International Law AE Anton 3ed (2011) 491.

265 They refer to Collins et al Dicey, Morris and Collins on the Conflict of Laws 11ed 1203; and North and Fawcett Cheshire and North's Private International Law 11ed (1987) 481.

266 Anton and Beaumont Private International Law 278. Beaumont and McEleavy Private International Law 491 refer the reader to Anton and Beaumont's second edition (Anton and Beaumont Private International Law 2ed (1990)) for further detail. Beaumont and McEleavy further tentatively suggest that capacity, in contracts concluded between parties in different countries (when the Rome I Regulation does not apply), should be governed by the personal law or the putative proper law of the contract.

267 Anton and Beaumont Private International Law 604; also Beaumont and McEleavy Private International Law 940. The authors refer to Story Commentaries on the Conflict of Laws, Foreign and Domestic 2ed (1841) 618: "It may be laid down as a general principle of the common law that a party must have a capacity to take according to the law of the situs, otherwise he will be excluded from all ownership." 
in $1948 .^{268}$ These suggestions were two-fold: first, a contract is not void due to incapacity if the contractants are capable in terms of the putative proper law; and, secondly, a contractant incapable according to the putative proper law should not be allowed to rely on his or her incapacity if he or she possesses capacity in terms of the lex domicilii. The putative proper law referred to here should be objectively ascertained because parties cannot confer capacity on themselves by merely selecting an unconnected law. ${ }^{269}$

\section{Summary}

The Scottish authors hold dissimilar views on the law applicable to contractual capacity. Anton and Beaumont draw a clear distinction between mercantile and non-mercantile contracts. In the case of the former, the lex loci contractus should apply and, in respect of the latter, the lex domicilii. ${ }^{270}$ They reject the application of the proper law of contract to capacity in general. ${ }^{271}$ The authors support the application of the lex situs to capacity in respect of contracts relating to immovable property. ${ }^{272}$ Crawford and Carruthers, on the other hand, do not express clear support for any of the legal systems to govern capacity. However, by referring to Cheshire's suggestion in 1948, they seem to endorse the alternative application of the putative objective proper law and the lex domicilii. ${ }^{273}$ Application of the proper law subjectively ascertained is clearly not accepted in Scottish private international law.

268 Cheshire International Contracts: Being the Fifteenth Lecture on the David Murray Foundation the University of Glasgow (1948), referred to by Crawford and Carruthers International Private Law 437.

269 Crawford and Carruthers International Private Law 437.

270 Anton and Beaumont Private International Law 276. Also see Beaumont and McEleavy Private International Law 491.

271 Anton and Beaumont Private International Law 278.

272 Anton and Beaumont Private International Law 604; also Beaumont and McEleavy Private International Law 940.

273 Crawford and Carruthers International Private Law 437, as per Cheshire's view (Cheshire International Contracts).

274 Anton and Beaumont Private International Law 437. Also see Beaumont and McEleavy Private International Law 491 and Crawford and Carruthers International Private Law 437. 